\title{
The Effect of Charismatic Leadership on the Sustainability of Tourism Destination with Entrepreneurship Orientation and Community Empowerment as a Mediator
}

\author{
Glory Aguzman ${ }^{1}$ Adler Haymans Manurung ${ }^{2}$ Yosef Dedy Pradipto ${ }^{3}$ and Lim \\ Sanny ${ }^{4}$ \\ ${ }^{I}$ Management Department, Binus Business School, Binus Entrepreneurship Centre, Bina Nusantara, Jakarta, \\ Indonesia 11480 \\ ${ }^{2}$ Management Department, Binus Business School Doctor Research Management, Bina Nusantara, Jakarta, \\ Indonesia 11480 \\ ${ }^{3}$ Department of Psychology, Faculty of Humanities, Bina Nusantara University, Jakarta, Indonesia 11480. \\ ${ }^{4}$ Management Department, BINUS Business School Master Program, Bina Nusantara University, Jakarta, \\ Indonesia 11480 \\ *Correspondence author email: guzman@binus.edu
}

\begin{abstract}
Tourism is an industry that continues to grow in Indonesia and has become one of the most active sectors in the last four years. In Indonesia, tourism continues to rise in ranking in terms of visitors on a local scale, both Asia and the world. Foreign exchange income from tourism is the focus of the Indonesian government. However, the government's focus is not enough because there is still a tourism destination that is not sustainable. This study analyzes the factors that determine the sustainability of a tourist destination, namely measuring the Leadership of tourism management in tourism destinations, namely from the charismatic leadership style and the entrepreneurial orientation of the conscious tourism groups to achieve sustainable tourism destinations. This study measures the four variables with smart PLS, namely the results of respondents as many as 283 people in four tourist destinations included in the top 100 world sustainability tourism destination. Two hundred eighty-three respondents were members of the tourism awareness group (Pokdarwis) in each tourist destination. The result of his analysis is that charismatic Leadership significantly affects entrepreneurship orientation, but entrepreneurship orientation does not affect substantially sustainable tourism destination, and the results remain insignificant if entrepreneurship orientation is the mediating variable of charismatic Leadership with the sustainable tourism destinations; however, after adding the community empowerment variable, the results will be significant.
\end{abstract}

Keywords: Charismatic Leadership, Tourism Destination, Entrepreneurship Orientation

\section{INTRODUCTION}

Indonesia's potential as an island nation and completeness of natural attractions such as mountains, seas, caves is a gift from the Almighty, which is not owned by other countries. Indonesia doesn't have ice faults because the climate is subtropical. The Indonesian government has prioritized the tourism industry as the main thing in obtaining state foreign exchange, so it is expected to be a significant foreign exchange contributor after natural resources such as oil and gas. But in the development of tourism is not only its formation or story, but its sustainability needs to be a significant factor, and sustainability is inseparable from preservation efforts in every tourist area.

The government's focus in helping to manage destinations in each region is to provide economic benefits to the surrounding community and conciliation to keep the tourist destination running and sustainable, and this is the goal of management. But the concentration of the government or the administration is not enough to create a sustainable tourist destination. According to the final report of the classification of the study of Sleman Regency Tourism Village [18] several Tourist Villages in the Yogyakarta region still fail in their management so that for the Village to become a tourist destination fails due to mismanagement or problems of a management agency

In the management of a tourist destination, there needs to be an organization derived from Leadership and researchers want to focus on a charismatic leadership style [3], as well as the need for an entrepreneurial orientation used by a community institution that is an institution created from Community empowerment. With the hope that 
these three variables can be able to develop the sustainability of a tourist destination. This research aims to confirm charismatic Leadership can influence entrepreneurial orientation, Entrepreneurial orientation will affect the sustainability of tourist destinations, Entrepreneurial orientation, and community empowerment can jeopardize the sustainability of tourism destinations. These variables are expected to be a suiTABLE model for creating the sustainability of tourist destinations.

To achieve sustainable development goals in a developing country, the focus of a more locally controlled and participatory community-based ecotourism contributes to sustainable development [21]. Tourism will provide sustainability to an area where tourism contributes to ecological, sociocultural, and economic goals [8]. Since the emergence of sustainability as a benchmark for tourism development, there have been indicator parameters that serve to measure the impact of tourism [20]. Stakeholder participation is one indicator of environmental variables that are the determining factor in the sustainability of tourism areas [13].Sustainable village development depends on agricultural produce, which is the Village's main activity [6]. The book Reframing Sustainable Tourism [12] defines tourism's sustainability to place activities crossed marketing, infrastructure, programs, and policies that are simultaneously environmentally appropriate, socially accepTABLE, and economically viable. This definition defines the development of several businesses sliced into each other to achieve social and economic goals.

Samir, House, and Arthur also developed a charismatic leadership theory based on self-concept [16]. The development of a tourist destination is very close so that the goal becomes a sustainable tourist destination, and indicators of articulation strategy and vision can measure the measurement of the leader of an organization or community, sensitivity to the environment, and sensitivity to the needs of its members [6]. In strategic Leadership, it is necessary to identify deficits in human resources that need immediate attention to facilitate; using social capital, the organization's actions can increase the resources needed [9].

A leader expressed to be highly charismatic when concerned has three indicators as follows: (1) Confidence in a high level (2) Dominant and (3) Self-confidence over what he believes. Charismatic Leadership is Leadership that wants to achieve its goals with a strategic vision to influence individuals, and try to enable their vision to be felt by all and also feel the needs and needs of brand followers, and perform unconventional and extraordinary behavior to drive the achievement of organizational goals [4].
Previous studies have discussed entrepreneurship's orientation as an innovation activity [17]. Entrepreneurial orientation refers to companies' overall competitive direction [5] that come into contact with Practice, process, and decision-making [2]. Entrepreneurial orientation is a characteristic of businesses that describe companies' ability to compete to adapt and perform effectively in a competitive environment [22]. As stated in previous research by Clovin and Slevin 1989 saying under Entrepreneurial Orientation as a process, the company's structure and behavior are characterized by innovativeness, proactiveness, and risk-taking.

Rappaport, 1981 empowerment related to the word strength in English discussion is analogous to the concept of "Leans on" or "lean" to act on a specific purpose. The community empowerment that will be discussed in this dissertation is a tourism aware group (Pokdarwis), in the guidebook of The Tourism Aware group [14] explaining that: "Increasing the role of the community in tourism development requires various empowerment efforts so that the community can play a more active and optimal role and at the same time receive positive benefits from development activities carried out to improve its welfare."

According to Conger, 1985, empowerment is a social process, and in the academic opposition to the community, empowerment is how society gained control [11]. The meaning of power implies that it can choose the community or have depravity of acting [19]. Community empowerment is about improving social justice, equality, and emancipation [23].

\section{RESEARCH METHODS}

This research is inconsistent with the tourist destinations that have conscious tour groups. Based on researchers' informal data, there are approximately 100 tourist destinations that were successfully collected through the Pokdarwis forum Indonesia. In this study, researchers determined four tourist destinations, namely Pemuteran Tourism Village, Bali, Panglipuran Tourism Village, Bali, Pentingsari Tourism Village, Yogyakarta, and Nglanggeran Tourism Village, Yogyakarta. The researchers set the alpha at a level of 0.05 and planned with a calculation using a scale of 7 points. The error received was 3 percent, with the estimated number of deviation standards already calculated was 1,167 . Based on these calculations, the required sample number is at least 118 people [1], and from that minimum, the researchers have gathered 283 Respondents. Primary data collection was conducted using questionnaires using a Likert scale with 5 points, which showed a scale of $5=$ enormously 
agreeable, $4=$ agree, $3=$ neutral, $2=$ disagree, and 1 $=$ strongly disagree.

For data analysis and equation modeling, SmartPLS software is used. These indicators are specifically designed to be tested in the tourism industry. Validity tests will be measured in two ways. First, construct operationalization is taken from an extensive review of library studies to improve the validity of the construct and be cumulative from previous studies. Designing structural (inner model), i.e., with direct influence testing and indirect influence testing.

\section{RESULTS AND DISCUSSION}

Previous research conducted by Huang, Cheng, \& Chou, 2005 found that charismatic Leadership affects employees' extra efforts to work, giving satisfaction to CEOs and organizational commitment mediated by perceptions of people's values. These findings provide evidence that charismatic leadership relationships and corporate values are significant. In addition to these findings, the study yielded significant organizational values to performance. Huang, Cheng, and Chou's research, 2005 , became the cornerstone of this hypothesis to be confirmed in this study.

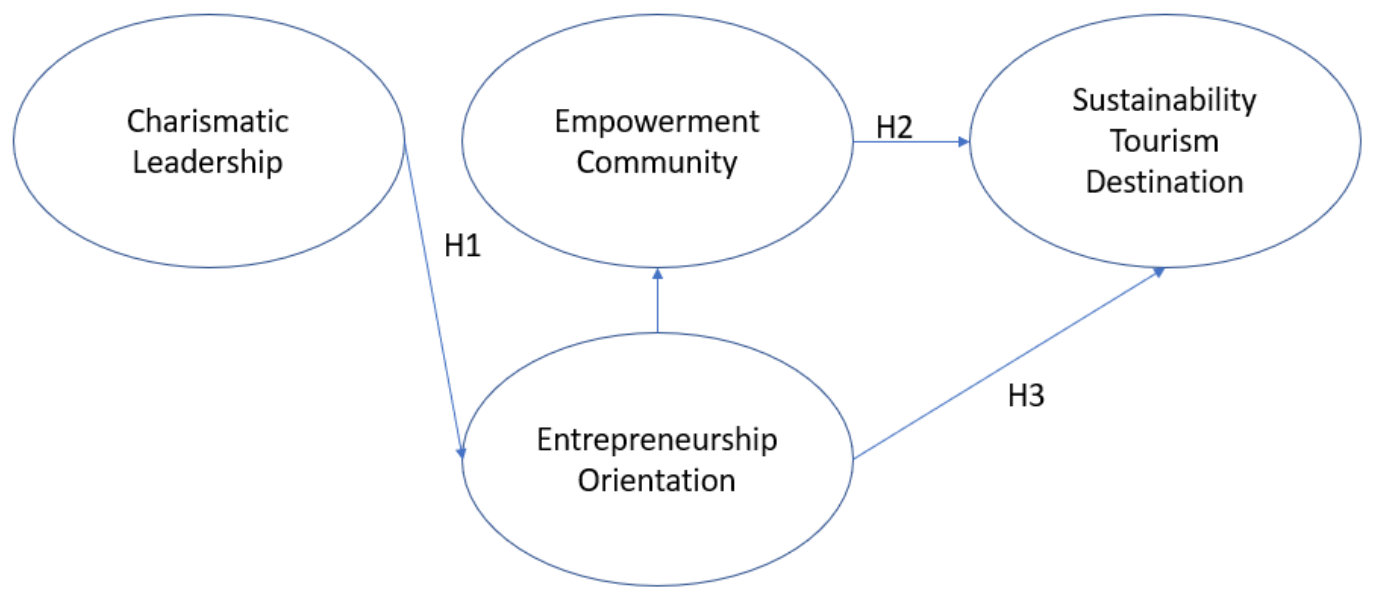

FIGURE 1. The Effect Of Charismatic Leadership On The Sustainability of Tourism Destination with Entrepreneurship Orientation and Community Empowerment as A Mediator

TABLE 1. Direct Impact

\begin{tabular}{|l|l|l|l|}
\hline \multirow{2}{*}{ Hypothesis } & \multicolumn{3}{c|}{ Path Coefficient } \\
\cline { 2 - 4 } & \multicolumn{1}{|c|}{$\begin{array}{c}\text { Original } \\
\text { Sample }\end{array}$} & $\begin{array}{c}\text { T-Values }>1.65 \text { dan T- } \\
\text { Values }>1.96\end{array}$ & $\begin{array}{c}\text { P-Values } \leq 0.5 \text { dan } \\
\text { P-Values } \leq 0,10\end{array}$ \\
\hline $\begin{array}{l}\text { H1: Charismatic Leadership effect } \\
\text { Entrepreneurship Orientation. (X1->X2) }\end{array}$ & 0.848 & 37.126 & 0.000 (sig) \\
\hline $\begin{array}{l}\text { H2: Entrepreneurship Orientation effect } \\
\text { Sustainability Tourism Destination (X2- } \\
>Y \text { Y) }\end{array}$ & 0.047 & 0.438 & $\mathbf{0 . 6 6 2}$ (not sig) \\
\hline
\end{tabular}

Hypothesis 1, The P-value of the influence of charismatic Leadership on community empowerment (X1 à Y1) is 0.042 , with a positive marked path of 0.270 . Because the P-value of $<0.1$ and the coefficient of positive pathways can be concluded, charismatic Leadership has a positive and significant effect on community empowerment. This shows that the better the charismatic Leadership of Pokdarwis, the better the empowerment of the community in the area, so on the contrary.

Hypothesis 2, the P-value influence of entrepreneurial orientation on tourist destinations' sustainability (X2 à Y2), is 0.622 with a positively marked path of 0.047 . Because the value of P-value $>0.1$ can be concluded that it turns out directly, entrepreneurial orientation does not affect the sustainability of tourist destinations in the region. This shows that areas with high entrepreneurial exposure do not always support the sustainability of tourist destinations. In research, Entrepreneurial orientation affects a company's strategy in achieving its performance but does not directly improve a company's performance results. Entrepreneurial orientation is an ability implied by Leadership by an 
institution and cannot stand alone to produce a goal.

TABLE 2. Inirect Impact

\begin{tabular}{|l|l|l|l|}
\hline \multicolumn{2}{|c|}{ Hipotesis } & \multicolumn{3}{c|}{ Path Coefficient } \\
\cline { 2 - 4 } & $\begin{array}{c}\text { Original } \\
\text { Sample }\end{array}$ & $\begin{array}{c}\text { T-Values }>1.65 \text { dan T- } \\
\text { Values }>1.96\end{array}$ & $\begin{array}{c}\text { P-Values } \leq 0.5 \text { dan } \\
\text { P-Values } \leq 0,10\end{array}$ \\
\hline $\begin{array}{l}\text { H3: characteristic Leadership on the } \\
\text { sustainability of tourist destinations } \\
\text { mediated by entrepreneurial orientation } \\
\text { and community empowerment (X1->X2- } \\
>\mathrm{X} 3->\mathrm{Y})\end{array}$ & 0.139 & 2.345 & $\mathbf{0 . 0 1 9}$ \\
\hline
\end{tabular}

Hypothesis 3, The value of $\mathrm{P}$-value of indirect influence of characteristic Leadership on the sustainability of tourist destinations mediated by entrepreneurial orientation and community empowerment ((X1->X2->X3->Y) is 0.019, because of the significant $\mathrm{P}$-value value ho rejected and concluded that charismatic Leadership could indirectly affect the ban on tourist destinations by being mediated by entrepreneurial orientation and community empowerment.

\section{CONCLUSION}

This shows that good charismatic Leadership will improve the people's entrepreneurial orientation in the area, which will further support the empowerment of the people in the area so that the better the sustainability of tourist destinations in the area. As the cornerstone of this hypothesis, Huang, Cheng, \& Chou, 2005 got the result that charismatic Leadership affected employees' extra effort to work, providing satisfaction to the $\mathrm{CEO}$, and organizational commitment mediated by the perception of people's values. These findings provide evidence that charismatic leadership relationships and organizational values are significant and confirm this hypothesis.

The entrepreneurial orientation will be maximized through an institution led by charismatic Leadership; Charismatic leaders can be emulated by being the leadership style of an organization engaged in tourism.

\section{ACKNOWLEDGMENTS}

I am enormously grateful to Binus University who has ask me to put this journal of this grant, thanks to our beloved family for the love and support of morale, colleagues and partner that helped the implementation of this research.

\section{REFERENCES}

[1] Bartlett, J. E., Kotrlik, J. W. K. J. W., \& Higgins, C. (2001). Organizational research:

Determining the appropriate sample size in survey research. Information Technology, Learning, and Performance Journal, 19(1), 43.

[2] Basso, O., Fayolle, A., \& Bouchard, V. (2009). Entrepreneurial Orientation: The Making of a

Concept. The International Journal of Entrepreneurship and Innovation, 10(4), 313-321.

https://doi.org/10.5367/000000009790012 327

[3] Choi, J. (2006). A Motivational Theory of Charismatic Leadership: Envisioning, Empathy, and Empowerment. Journal of Leadership \& Organizational Studies, 13(1), 24-43. https://doi.org/10.1177/107179190701300 10501

[4] Conger, J. A., Kanungo, R. N., \& Menon, S. T. (2000). Charismatic Leadership and follower effects. Journal of Organizational Behavior, 21(7), 747-767. https://doi.org/10.1002/10991379(200011)21:7<747::AIDJOB46>3.0.CO;2-J

[5] Covin, Jeffrey, G., \& Slevin, Dennis, P. (1989). Strategic Management of Small Firms in Hostile and Benign Environments. Strategic Management Journal, 10(1), 7587. Retrieved from file://C:/Users/Ichiyanagi/Downloads/Stra tegic_Management_of_Small_.pdf

[6] Ekmekcioglu, E. B., \& Aydintan, B. (2018). The effect of charismatic Leadership on coordinated teamwork: a study in Turkey. https://doi.org/10.1108/LODJ-07-20170193

[7] Emelyanova, L. L., Kropinova, E. G., \& Voloshenko, K. J. (2015). The integrated approach to the sustainable development of rural areas: the case for the agricultural sector in the Kaliningrad region of the Russian Federation, 11(2), 158-177.

[8] García-melón, M., Gómez-navarro, T., \& Acuña-dutra, S. (2012). A combined ANP- 
Delphi approach to evaluate sustainable tourism. Environmental Impact Assessment Review, 34 , 41-50. https://doi.org/10.1016/j.eiar.2011.12.001

[9] Hitt, M. A. (2000). The Essence of Strategic Leadership : Managing Human and Social Capital, 4-5.House, R. (1976). A 1976 Theory of Charismatic Leadership. Retrieved from https://files.eric.ed.gov/fulltext/ED133827. pdf

[10] Huang, M. P., Cheng, B. S., \& Chou, L. F. (2005). Fitting in organizational values: The mediating role of person-organization fit between CEO charismatic leadership and employee outcomes. International Journal of Manpower, 26(1 SPEC. ISS.), 35-49. https://doi.org/10.1108/014377205105872 62

[11] Lawson, L., \& Kearns, A. (2010). “ Community Empowerment' in the Context of the Glasgow Housing Stock Transfer, 47(June), 1459-1478. https://doi.org/10.1177/004209800935361 9

[12] Mccool, S. F. (2016). Reframing Sustainable Tourism. (K. Bosak, Ed.) (Volume 2). New York: Springer.

[13] Pasape, L., Anderson, W., \& Lindi, G. (2014). Anatolia: An International Journal of Tourism and Hospitality Research Assessment of sustainable ecotourism indicators in Tanzania, (November 2014), 37-41.

https://doi.org/10.1080/13032917.2014.91 2244

[14] Rahim, F. (2012). В и k и P ed o m a n Kelompok Sadar Wisata.

[15] Rappaport, J. (1981). In praise of paradox: A social policy of empowerment over prevention. American Journal of Community Psychology, 9(1), 1-25. https://doi.org/10.1007/BF00896357

[16] Roberts-Miller, P. (2019). Demagoguery, Charismatic Leadership, and the Force of Habit. Rhetoric Society Quarterly, 49(3), 233-247.

https://doi.org/10.1080/02773945.2019.16 10638
[17] Salavou, H., \& Lioukas, S. (2003). Radical product innovations in SMEs: The dominance of entrepreneurial orientation. Creativity and Innovation Management, 12(2), 94-108. https://doi.org/10.1111/1467-8691.00272

[18] Soemargono, F. (2018). KAJIAN KLASIFIKASI DESA WISATA KABUPATEN SLEMAN. DINAS PARIWISATA KABUPATEN SLEMAN, 13(1), 15-20. https://doi.org/10.3406/arch.1977.1322

[19] Somerville, P. (1998). Empowerment through the residence. Housing Studies, 13(2), 233-257. https://doi.org/10.1080/02673039883425

[20] Torres-delgado, A. (2013). Tourism Geographies : An International Journal of Tourism Space, Place and Using indicators to assess sustainable tourism development : a review, (June 2014), 37-41. https://doi.org/10.1080/14616688.2013.86 7530

[21] Twining-Ward, L., \& Butler, R. (2010). Implementing STD on a Small Island: Development and Use of Sustainable Tourism Development Indicators in Samoa Implementing STD on a Small Island: Development and Use of Sustainable Tourism Development Indicators in Samoa, 9582.

https://doi.org/10.1080/096695802086671 74

[22] Wales, W. J., Patel, P. C., \& Lumpkin, G. T. (2013). In pursuit of greatness: CEO narcissism, entrepreneurial orientation, and firm performance variance. Journal of Management Studies, 50(6), 1041-1069. https://doi.org/10.1111/joms.12034

[23] White, S. C. (1996). Depoliticising development: The uses and abuses of participation. Development in Practice, 6(1), https://doi.org/10.1080/096145296100015 7564 